\title{
The Family Instructions of Ji Dan Recorded in the Book of Documents
}

\author{
Ho-kin Tong ${ }^{1}$ \\ ${ }^{1}$ Department of Literature and Cultural Studies, Hong Kong Institute of Eduation, Hong Kong SAR, China \\ Correspondence: Ho-kin Tong, Department of Literature and Cultural Studies, Hong Kong Institute of Education, \\ 10 Lo Ping Road, Tai Po, Hong Kong SAR, China. Tel: 852-2948-7970. E-mail: hktong@ied.edu.hk
}

Received: November 9, 2014 Accepted: November 14, 2014 Online Published: December 29, 2014

doi:10.5539/ach.v7n1p240

URL: http://dx.doi.org/10.5539/ach.v7n1p240

\begin{abstract}
The five chapters of family instruction "Announcement to the Prince of Kang", "Announcement about Drunkenness", "Timber of the Rottlera", "Against Luxurious Ease" and "Establishment of Government" attributed to Ji Dan in the Book of Documents are studied with reference to the political and social context of the Western Zhou period. In these chapters, Prince Kang and King Cheng of Zhou are reminded by Ji Dan to develop personal quality such as cultivation of virtue, modelling of exemplar Shang kings and observance of clan seniors' instructions as well as rule the people by education, law and punishment, virtuous officials, and caring strategies. These family instructions which may be updated or created in the late Western Zhou are based on the beliefs "observe the will of Heaven" and "love the people" aiming to sustain and pass on the family-held sovereignty. A framework of family sustainability is constructed accordingly with reference to ethical concepts of filial piety and paternal concern. This framework can be extended from the royal family instruction to other social classes as sustainability of family is the major responsibility of Chinese while cultivation of virtue and development of administrative skills are still two key areas of education for Chinese.
\end{abstract}

Keywords: family instruction, family sustainability, Ji Dan, Book of Documents, Western Zhou period

\section{Introduction}

Starting from the period of Spring and Autumn (Chunqiu c.771 BC - 476 BC), family instruction (jiaxun) emerged as a major family education media in imperial China. However, the ancient family instruction which shapes most thinking and behaviour of Chinese in imperial China has not attracted sufficient research attention from scholars. Currently, the research focus in this area is on Yan Zhitui's (531-591) Yans' family instruction (Yanshi jiaxun). Some other major works in a broader sense of the major research outputs in this area include: Transmitted Chinese family instruction (Zhonghua chuanshi jiaxun) $(\mathrm{Li}, 1998)$ which is a compilation of family instruction from the Pre-Qin period (before $221 \mathrm{BC}$ ) to modern China; General discussion on the thoughts of traditional family instruction (Chuantong jiaxun sixiang tonglun) (Wang, 2006), a thematic study on topics related to moral standard and family education; Discussion on the history of Chinese family instruction (Zhongguo jiaxunshi lungao) (Zhu, 2008), a historical account of family instruction from its origin to modern China; Study on family instruction of the Hanwei and Liuchao Period (Hanwei liuchao jiaxun yanjiu) (Kang, 2009), a historical study of family instruction for the periods Han to Six Dynasties (Liuchao, $202-589$ BC). Tong (2013) observed that most of the transmitted Pre-Qin family instructions are instructions from senior members of the upper class to their junior clan members on how to behave as lords and senior officials. It seems that these texts perform some political and ethical functions that have great impact on the attitude towards ruling and behaviour of senior officials in early China. Fu and Shi (2008) claimed that the Pre-Qin period was the infancy stage of family instruction in China while Zeng (2006) proposed that Ji Dan (? - 1105 BC), Duke Dan of Zhou, an influential member of the early royal family of Zhou (c.11046-256 BC), was the founder of Chinese family instruction. A study of these ancient family instructions can provide information on how nobles perceive family education in relation to the political and social contexts of the Western Zhou period.

The Book of Documents is a collection of historical prose with literary beauty and political views attributed to figures of ancient China. It was one of China's oldest literary controversies, between proponents of the "New Text" version and the "Old Text" versions of the text. Its original texts were destroyed in the Qin period (221-2-6 BC) and then preserved by Fu Sheng (fl. $3^{\text {rd }}-2^{\text {nd }}$ century BC) in the Western Han period (206 BC-24 AD) while the "Old Text” version was supposedly discovered by Kongzi’s (551-479 BC) descendants Kong Anguo (ca. 156 - ca. 74 
BC) in the wall of Kongzi's clan estate in the $2^{\text {nd }}$ century BC. The "Old Text" version was then lost and rediscovered in the $4^{\text {th }}$ century $\mathrm{AD}$ and became the imperial version since the Tang period (618-907). In the Qing period (1644-1912), Yan Ruoqu (1636 - 1704) demonstrated that the additional "Old Text" chapters not contained in the "New Text" version were actually fabrications "reconstructed" in the 3rd or 4th centuries AD. The excavated scripts on bamboo slips from tombs of the state Chu in Jingmen, Hubei between 1993 and 2008 are believed to date from the late Warring States period (475 BC to $221 \mathrm{BC}$ ) around $300 \mathrm{BC}$ which predates the burning of the books during the Qin dynasty (Liao, 2001). The Guodian Chu Slips and the Shanghai Museum corpus contain quotations of previously unknown passages of the work (Liao, 2001; Shaughnessy, 2006). The Tsinghua Bamboo Slips contain the "New Text" chapter "Golden Coffer" (Jinteng) with minor textual differences and some chapters in the same style which are not transmitted in the received text. It also includes documents that are versions of the Old Text chapters such as the three chapters of "Charge to Yue" (yueming) but the contents are completely different from the chapters confirming that the "rediscovered" versions are forgeries (Tsinghua University News, 2013). In this paper, Gu Jiegang and Liu Qiyu's (2005) Discussion, Annotation and Translation on the Book of Documents (Shangshu jiaoshiyi lun) is used as the primary text of the Book of Documents as it is currently the most comprehensive study of the Book of Documents. Only the chapter titles and page numbers of the quotes from this book are cited in the paper. In addition, James Legge's (1960) English translation of the Book of Documents will be adopted with necessary revision in this paper.

Based on the Book of Documents, Sun and Li (1995) pointed out Ji Dan's three views on education of royal family leaders: (1) they should be educated early; (2) they should educate their family members; (3) ethic and rulership should be key learning areas for royal family leaders. These views are recorded in the chapters "Announcement to the Prince of Kang" (Kanggao), "Announcement about Drunkenness" (Jiugao), "Timber of the Rottlera" (Zhicai), "Against Luxurious Ease" (Wuyi) and "Establishment of Government" (Lizheng) in the Book of Documents. The aims of the paper are to: (1) study what instructions of Ji Dan are recorded and why they are recorded with reference to the political and social context of the Western Zhou period; (2) construct a framework to explain the function of ancient Chinese family instruction. This framework is important since ethics and ruling are the two main areas of family education in imperial China (Liu, 2002) and it helps one to understand why and how ethics and politics are integrated in the tradition of Chinese culture. This theoretical framework may be able to provide a possible answer to why the Book of Documents is taken as a classic textbook for nobles in the Pre-Han periods as well as for all the people in later periods.

\section{The Early Family Instruction in the Book of Documents}

The chapters "Announcement to the Prince of Kang", "Announcement about Drunkenness", "Timber of the Rottlera", "Against Luxurious Ease" and "Establishment of Government" are five family instructions attributed to Ji Dan in the Book of Documents. However, pointing to differences in language between the announcements and the Zhou bronzes, Kern (2009) argues that "these texts were either partially updated or wholly created not by the sage rulers of the early Western Zhou but by their distant, late-Western or early Eastern Zhou descendants who commemorated them" (p. 145). Kern also states that in addition to the "multiple layers of textual redaction that extended over many centuries into the Han times (206 BC-220 AD)" (p. 146), "all our transmitted sources speak about the early Western Zhou period are likely later idealizations that arose in times of dynastic decline and from a pronounced sense of loss and deficiency: first in the middle and later stages of the Western Zhou, that is, after King Zhao's (r.977/75-957 BC) disastrous campaign south; and second in the time of Confucius (551-479 BC) and the following half millennium of the Warring States and the early imperial period" (p. 146). The term "Mandate of Heaven" (tianming) which does not appear frequently in early Western Zhou bronze inscriptions appears as "singularly central and critical to the political legitimacy and religious underpinnings of early Western Zhou rule" (Kern, 2009: p. 148). In addition, the many records of Ji Dan in the Yizhoushu (Lost Book of Zhou) are an attempt to emphasize the great contribution and supreme status of Ji Dan (Huang, 1992). The five texts of family instruction in the Book of Documents are typical examples of representations of commemoration of royal descendants of the late-Western (1046-771 BC) or early Eastern Zhou period (770 221 B.C.). The key figures that appeared in these commemorations, King Wen (c. 110o BC) and his son King $\mathrm{Wu}$ (c.1050 BC), are the two sage kings while Ji Dan is a virtuous official of the early Western Zhou period. They made great contributions to the establishment of the dynasty and are highly respected by all state lords and descendants of the royal Zhou family. Their ethical rulership associated with "Mandate of Heaven" and virtue is represented in these five chapters in order to restore the supreme political legitimacy of the royal Zhou family. In the period of late Western Zhou, the royal family lost its authority and influence over feudal lords due to breaking down of the patriarch system and rite system. The royal Zhou family is no longer respected by feudal lords and mergers are common among states. The commemorative representation of instructions of the sage 
kings and virtuous officials is a way to remind members of the royal family to follow the rulership of their ancestors as well as re-informing feudal lords about the great appointment to Heaven of the Zhou family. The hermeneutic approach with reference to the social and political environment of the Western Zhou period will be adopted to interpret the instructions in these commemorative representations of Ji Dan recorded in the Book of Documents. The findings of the above discussion will then be used to formulate a framework of family sustainability attributed to explain the purpose and function of these family instructions.

\section{Ji Dan's Instructions Recorded in the "Announcement to the Prince of Kang", "Announcement about Drunkenness", "Timber of the Rottlera", "Against Luxurious Ease" and "Establishment of Government"}

Tong (2013) defined Chinese family instruction as "a major source of spiritual education from clan seniors to juniors and from husbands to wives in ancient China which aims at guiding people to understand themselves and maximize their personal potential so as to sustain their clans in the inter-connected society" (p. 205). This is a spiritual interpretation which emphasizes that the instructions are delivered from clan senior to clan juniors. In the period of Western Zhou, from perspectives of social structure and legal relation, core family (jiating) refers to a unit which is formed through mirages in which members live together and share their resources; family clan (jiazu) refers to a unit which is formed through blood relations in which although members do not live together and share resources, they are connected with political, economic and legal responsibilities; ancestral clan (zongzu) refers to a unit in which members carry the same surnames and share just moral responsibility (Wang, 2007). In ancient times, the Chinese term "jia" always included these three meanings and from a broad sense of view, the family instruction can be defined as a teaching and learning media delivered by senior members of the same ancestral clan, family clan and small core family to their junior members. This definition is adopted in the paper.

Accordingly, the chapters "Announcement to the Prince of Kang", "Announcement about Drunkenness", "Timber of the Rottlera", "Against Luxurious Ease" and "Establishment of Government", in the Book of Documents, are to a great extent, commemorative representations of descendants of the royal Zhou family. In these five chapters, Ji Dan is represented as a clan senior who delivers his speeches to his clan juniors Kangshu (Ji Feng, c.1042 BC) and King Cheng (Ji Song, 1055 BC - 1021 BC; r.1042 BC - 1021 BC). The "Announcement to Prince Kang" is an announcement of appointing Kangshu (c.1042 BC), younger brother of Ji Dan, to rule the Wei State in the fourth year of his regency (Gu \& Liu, 2005).

The "Announcement about Drunkenness" and the "Timber of the Rottlera" are two chapters of speech following the "Announcement to the Prince of Kang" to instruct Kangshu how to rule in an ethical way. In the "Against Luxurious Ease" it is recorded that Ji Dan reminds his nephew King Cheng not to live in ease and know about the difficulty of farming and life of poor people while the "Establishment of Government" records Ji Dan's views on how to establish governmental institution and appoint officials with reference to the history of Xia (c. 2070 BC-c. 1600 BC) and Shang (c. 1600 BC-1046 BC). It is interesting that Ji Dan, being a senior official, can teach King Cheng, the official ruler of the empire, how to manage the nation. The supreme status of Ji Dan in the mind of descendants of the Zhou family is represented here because of his great contribution to the Zhou sovereignty. This also demonstrates the supreme status of clan seniors to clan juniors in ancient China.

\subsection{Personal Quality of Rulers}

According to the five chapters, a ruler who wants to secure his sovereign must practise the "virtue of reverence". The "virtue of reverence" is a broad concept in the Western Zhou period which requires rulers to respect Heaven's will and ancestors, regulate themselves strictly, work hard for state affairs, be kind to the people, and only employ punishment in unavoidable circumstances. All these seem to be responses to the misbehaviour of the Yin rulers (Wang, 2009). However, not all the Yin rulers are tyrants and some of them can be role models for the Zhou rulers. In the chapter "Announcement about Drunkenness", on one hand, Ji Dan encourages Prince Kang to follow the wise kings of Yin from Tang, the Successful (Cheng Tang), down to Di Yi who have "completed their royal virtue and revered their chief ministers" (Jiugao, p. 1403; Legge, 1960b, pp. 406-407). On the other hand, he also reminds Prince Kang not to follow King Zhou of Yin who not only is addicted to drink but also "greatly abandoned to extraordinary lewdness and dissipation, for pleasure's sake he sacrificed all his majesty" (Jiugao, p. 1407; Legge, 1960b, p. 408). Ji Dan is represented as a wise and virtuous clan senior who always encourages Prince Kang and King Cheng to follow the instructions of King Wen and King Cheng in these five chapters. In the chapters "Announcement to the Prince of Kang", "Announcement about Drunkenness" and "Timber of the Rottlera", Ji Dan instructs Prince Kang how to rule the people of Yin and avoid being a drunkard while teaching King Cheng not to live in ease and how to organize the government structure and selection of officials in the "Against Luxurious Ease" and "Establishment of Government". The instructions of King Wen, King Wu and Ji Dan are represented in these speeches aiming at setting role models for descendants of the royal family. 


\subsection{Ideal Rulership Proposed by Ji Dan}

The ideal rulership of Ji Dan is presented in four major areas: (1) education; (2) laws and punishment; (3) principle of employing officials; (4) management strategies.

In the early Zhou, "cultivation of the virtue of reverence" and "love the people" were two major principles of ideal ruling. The virtue of reverence of the ruler is reflected by his performance in the above four areas and the assessment mechanism is the feeling of the people. If a ruler performed well in the four areas, the people would feel the love of their ruler and love him in return. In the chapter "Announcement to the Prince of Kang", Ji Dan reminds Prince Kang that: (1) if feudal lords have not educated their households, junior officials and heads of department in the state well but just apply terror and violence, they would set aside the royal charge and "in everything reverence the constant statutes, and so proceed to the happy rule of the people" (Kanggao, p. 1341; Legge, 1960b, p. 395); (2) the people of Yin could not be good if they receive no education. In the chapter "Announcement about Drunkenness", Ji Dan once again tells Prince Kang:

O Feng, in our western regions, the princes of States, the managers of affairs, and the youths, who in former days assisted our ancestor (King Wen), were all able to obey his lessons, and indulge in no excess of spirits; and so it is that I have now received the appointment which belonged to Yin (Jiugao, p. 1403; Legge, 1960b, p. 406).

Here Ji Dan emphasizes that education is an effective way to guide officials and the people to behave properly. However, there are always cases in which the aims of education cannot be achieved and therefore laws and punishment are required. In the chapter "Announcement to the Prince of Kang" Ji Dan has delivered very detailed instructions on how to apply laws and punishment to rule the people of Yin to Prince Kang: (1) have an serious understanding of penalties and exercise the death penalty to those who consistently and intentionally commit small crime; (2) let those prison officers know and follow the principle of how to decide a case so as to well-order these penal laws of Yin; (3) put a criminal in prison for five to ten days so as to have a good examination of the case before making a decision; (4) declare laws in order to impose punishments; (5) follow the regular laws of Yin to determine a case, and adopt correct and rational laws of Yin; (6) apply penal laws laid down by King Wen to punish those unfilial and unfriendly family members; (7) arrest and kill those state officers who never carry out the national laws and injure the sovereign in a quick way according to laws; (8) punish those lords who cannot educate their own families and sub-ordinates no matter at home or abroad to observe royal orders; (9) advocate laws and decrees; (10) rule the Yin people by taking account of the laws to reward (Kanggao, pp. 1291-1379; Legge, 1960b, pp. 381-398). It seems that the instructions remind Prince Kang to pay special attention to apply reward in addition to punishment, let all the people know about the system of laws and punish unfilial family members and those people who do not observe royal orders. Although this announcement is specifically to Prince Kang since it is a public announcement in an appointment ceremony, all other key lords and senior officials should be presented. In this circumstance, all these instructions may also apply to the people of Zhou. In short, as stated in the "Establishment of Government", rulers must carefully deal with punishment according to normal cases (Lizheng, pp. 1661-1710; Legges, 1960b, pp. 508-522).

Regarding the principle of employing officials, the chapter "Establishment of Government" records very important views attributed to Ji Dan. The basic principle is to "let us be thinking of officers of complete virtue, to regulate the people whom we have received" (Lizheng, pp. 1686-1687; Legge, 1960b, p. 519). In the record, Ji Dan reminds King Cheng not to employ officials just based on appearance rather than virtue or there will be no wise and intelligent ones to take up positions of the Three Ministries (sanzha): Ministry of Governmental Affairs (chengren), Ministry of Civil Affairs (changbo) and Ministry of Laws (zhunren). In the chapter, examples of Chengtang, the founder of the Shang period, and King Wen and King Wu of Zhou are quoted to demonstrate the function of these competent and virtuous ministers. Chengtang observes this principle and lets them harmonize all the people in the capital of Shang as well as display his bright virtue in every place under Heaven. It also states that King Wen and King $\mathrm{Wu}$ also follow this employment principle and understand the minds of the three ministers and their subordinates so as to do good things for the people according to the will of Heaven. The second principle of employing officials is to set up a government structure with clear roles and duties. It also states that in addition to the Three Ministries, the other key positions of the central government established by King Wen and King Wu are: administrator (renren), legal administrator (zhunfu), pastor (muzuo), guard (hufen), keeper of robes (zheyi), keeper of royal horses (quma), junior officer (xiaoyin), personal attendant (zuoyou xipu), overseer (baisi), and treasurer (shufu), while in the feudal states there are high and low ranking state lords (dadu xiaobai), men of arts (yiren), state officers (biaochen baisi), grand historiographers (taishi), chiefs of regions (yinbai), administer of land (situ), minister of war (sima), minister of work (sikong), and their subordinates. All these position holders must be competent and virtuous according to the record of Ji Dan's instructions in the "Establishment of Government". 
Moreover, management strategies of rulers are also important to the safety of sovereignty. In the "Announcement to the Prince of Kang" (Kanggao, pp. 1291-1379) Prince Kang is reminded to be tolerant towards the people of Yin since it is the will of Heaven to recognize the royal house of Zhou and make the Yin people newborn. Based on this vision, Ji Dan instructs Prince Kang to respect those who may be respected, threaten those who may be threatened, listen to good views of the Yin people, think deeply about wise instructions of those accomplished men of Yin-shang on how to understand the people's mind, try his best to carry on moral administration by using that to set the people of Yin at rest, remember the Yin people's good things, and be generous to their corvee, make their clothes and food rich so that Heaven will not blame you and cast you off when the people are in their tranquillity. Since it is difficult to rule a state which holds the former sovereignty, Prince Kang is advised to be careful and cautious and always act with all his heart. In the "Timber of the Rottlera" (Zicai, pp. 1421-1430), Ji Dan tells Prince Kang that a king should establish lords, educate and enlighten the people, and the key to educate lords and officials for a king is to enlighten the people and always put the people's heart at rest. According to the instructions, if Prince Kang could rule the people of Yin in such a way, he could keep the people of Yin from generation to generation.

The main instructions of "Against Luxurious Ease" (Wuyi, pp. 1530-1552) are to follow the previous virtuous kings of Yin and Zhou and not to rule the people in luxurious ease. In addition, in the chapter, King Cheng is encouraged to be dignified in manner and held in awe and veneration, taking the decree of Heaven as the standard to rule the people with respect and caution, understand the difficulty of farmers and the people, speak carefully to harmonize the people, observe the patriarch system, and be mild, kind and respectful. King Cheng is also reminded not to indulge in sightseeing, ease and pleasure, excursion and hunting, and let the people pay tribute or taxes for their luxurious living.

\subsection{Aims and Beliefs of the Ji Dan's Family Instruction in the Book of Documents}

Why are the family members of the royal Jis keen on sustaining their sovereignty? This question can be answered from materialistic and spiritual perspectives. The kings of Zhou are owners of all resources in the world including people and land. Once you can control resources, you can control the lives of yourselves and other people, which means authority. This is a matter of survival as if you have resources you are strong enough to protect yourself and others. The Jis family was a strong leader of various tribes in the west during the Shang period. After taking over the sovereignty of the Shang, the Jis family established the Zhou dynasty and became the leader of all tribes. This supreme status ensured rich materialistic life and authority for the Jis family. To maintain the family's sovereignty is the duty of all family members as it means continuation of the royal family. In that period, defeated tribes were taken as slaves and sacrifices for worships and burials (Wang, 2009). The loss of sovereignty does not only mean loss of resources but also means the risk of turning whole tribes into slaves and the extermination of an entire tribe. Hence all members have the obligation to safeguard the status of the royal family. From an ethical perspective, the concept of filial piety (xiao) carries three major functions in ancient China: (1) to make parents honourable; (2) not to put parents in blame; (3) to support parents' living (Kang 1992). The first two functions can be grouped together as they are related to the prestige of family while the third regards how to love parents within the family. In section one of "Li Lou" in the Book of Mengzi, it states that "There are three things which are unfilial, and to have no posterity is the greatest of them" (Liu, 1997, p. 2723; Legge, 1960a, p. 313). It is important to have male descendants to carry on the family name of the father's side as they are expected to worship their ancestors in temples and further develop their ancestors' great achievement (Kang, 1992). This concept has a strong impact on the mindset of many people in ancient and even contemporary China.

Based on these two materialistic and ethical rationales, royal family members have to try their best to sustain their sovereignty. This aim is supported by two beliefs: (1) observe Heaven's will; (2) love the people. The tribe of Zhou was under the rule of the Shang which linked the natural concept of Heaven (tian) with the Upper God (shangti) and attributed all things to orders of Heaven (tianmian) (Liu, 1996). These beliefs are in fact a response to the misbehaviour of the Xia and Yin rulers and the tradition of witchcraft and theocracy. The Xia is a nation of various tribes. At that time, the concepts of nation, tribe and clan were not clear and the tribe and the nation belonged to a combined conception (Wang, 2009). It was believed that the sovereignty was controlled by the power of witchcraft and theocracy evidenced by records in the Book of Mozi, the Classic of Mountains and Seas (Shanhai jing), the Records of the Grand Historian (Shiji), the Discourses of the States (Guoyu) (Wang, 2009). In the period of Shang, the people believed that there were three categories of Gods: (1) ti, the supernatural god who controls everything; (2) natural gods such as soils, rivers and mountains; (3) ancestral gods including virtuous kings and capable officials which is a strategy to consolidate sovereignty by linking it up with God and ancestors of the Yin. Wang (2009) states that this kind of linkage not only turns some leaders of Yin into tyrants 
but also leads to collapse of the Yin's sovereignty and brings the belief of witchcraft and theocracy from the peak to an end. In order to consolidate sovereignty, leaders of early Zhou conceptualized Heaven's decree in a way based on the virtue of rulers to justify their taking over of the Yin. In the chapter "Announcement of Duke Shao" (Shaogao) in the Book of Documents, it states:

We should by all means survey the dynasties of Xia and Yin. I do not presume to know and say, "The dynasty of Xia was to enjoy the favouring decree of Heaven for so many years," nor do I presume to know and say, "It could not continue longer." The fact was simply that, for want of the virtue of reverence, the decree in its favour prematurely fell to the ground. Similarly, I do not presume to know and say, "The dynasty of Yin was to enjoy the favouring decree of Heaven just for (so many) years," nor do I presume to know and say, "It could not continue longer." The fact simply was, that, for want of the virtue of reverence, the decree in its favour fell prematurely to the ground. The king has now inherited the decree - the same decree, I consider, which belonged to those two dynasties. Let him seek to inherit the virtues of their meritorious sovereigns (Shaogao, p. 1441; Legge, 1960b, p. 429-430).

Here, Ji Shi (Duke of Shao, died ca. 1000 BC) queried Heaven's decree by referring to the fall of Xia and Yin and the rise of Zhou. This quote demonstrates that the Jis believe that Heaven will get back its decree if the chosen one does not have the "virtue of reverence". This view also appears in another chapter "Announcement about Drunkenness":

I (Ji Dan) have heard it said likewise, that in these times the last successor of those kings (of Yin) was addicted to drink, so that no charges came from him brightly before the people, and he was reverently and unchangingly bent on doing and cherishing what provoked resentment. Greatly abandoned to extraordinary lewdness and dissipation, for pleasure's sake he sacrificed all his majesty. The people were all sorely grieved and wounded in heart, but he gave himself wildly up to spirits, not thinking of ceasing, but continuing his excess, till his mind was frenzied, and he had no fear of death. His crimes accumulated in the city of Shang and though the extinction of the dynasty of Yin was imminent, this gave him no concern, and he wrought not that any sacrifices of fragrant virtue might ascend to heaven. The rank odour of the people's resentments, and the drunkenness of his herds of creatures, went loudly up on high, so that Heaven sent down ruin on Yin, and showed no love for Yin - because of such excesses. There is not any cruel oppression of Heaven; people themselves accelerate their guilt, and its punishment (Jiugao, 1407-1408; Legge, 1960b, pp. 408-409).

In this quote, Heaven gets back the decree from Yin because of King Zhou's lewdness and misbehaviour of the Yin people. This common belief of early Western Zhou is recorded in most chapters attributed to early Zhou leaders in the Book of Documents as well as in records of the Book of Songs (Shijing) and bronze inscriptions in the Western Zhou. Typical examples are the poems "King Wen" (wen wang) and the "Da Ming" (Daming) of the Book of Songs (Liu, 1997: 502-506, 506-509) and the Tripod of Duke Mao in the King Xuan Period of Western Zhou (from 827 to 782 BC). (D.C. Lau Research Centre for Chinese Ancient Texts, 2014a). Heaven only appoints virtuous people to be lords of the people. The Zhou family is chosen to take over the Yin family because of the virtue of King Wen (Yang, 2008). Wang (2009) describes the emphasis on "virtue of reverence" as the basic principle of ruling is a move from theocracy to humanism and interprets the "virtue of reverence" in a broad sense to cover attitudes and behaviour such as to respect Heaven and ancestors, to love relatives and friends, to dedicate to ruling, to be careful in applying punishment, to promote education and to advocate virtue.

How can "virtue of reverence" be achieved? The people of Zhou learned from the fall of Yin that they had to love the people if they wanted to demonstrate their "virtue of reverence" to Heaven. In section one of the "Great Declaration" (Taishi one), it states:

I (King Wu) lead the multitude of you to execute the punishment appointed by Heaven. Heaven compassionates the people. What the people desire, Heaven will be found to give effect to (Lu, 1997, p. 181; Legge, 1960b, pp. 287-288).

King Wu thought that Heaven would follow the will of the people; if the people were for you Heaven was for you too and vice versa. In the second section of the "Great Declaration", it states "Heaven sees as my people see; Heaven hears as my people hear." (Lu, 1997, p. 181) This means that the feeling of people is a mirror of ruler's "virtue of reverence". If their rulers take care of their people, their people will display appreciation for Heaven and then the rulers can keep Heaven's decree. King Wu thought that people's discontent was seen and heard by Heaven and therefore he had to lead the alliance to conquer Yin. Based on this belief, Prince Kang is reminded to love the people by Ji Dan "as if you were guarding your own infants, and the people will be tranquil and orderly" 
(Kanggao, p. 1323; Legge, 1960b, p. 389). Ji Dan is recorded to reiterate the importance of loving the people in the chapter "Announcement about Drunkenness" which states "the ancients have said, "Let not men look only into water; let them look into the glass of other people" (Jiugao, p. 1409; Legge, 1960b, p. 409). From the speeches of early rulers of King Wu and Ji Dan discussed above, Heaven's will is linked up with the people's will which is in line with the proposal that there is a shift from theocracy to humanism during the transition period from Shang to Zhou. This kind of humanism requires the Zhou rulers to have a certain specific personal quality and rulership studied above.

\section{A framework of Family Sustainability of Ji Dan's Family Instruction}

As a senior clan member in the royal family of Early Zhou, Ji Dan is represented as a capable and virtuous official who has clear expectations of his clan juniors as discussed above. As discussed in previous sections, the main instruction in these five chapters of family instruction can be summarized in a framework as follows.

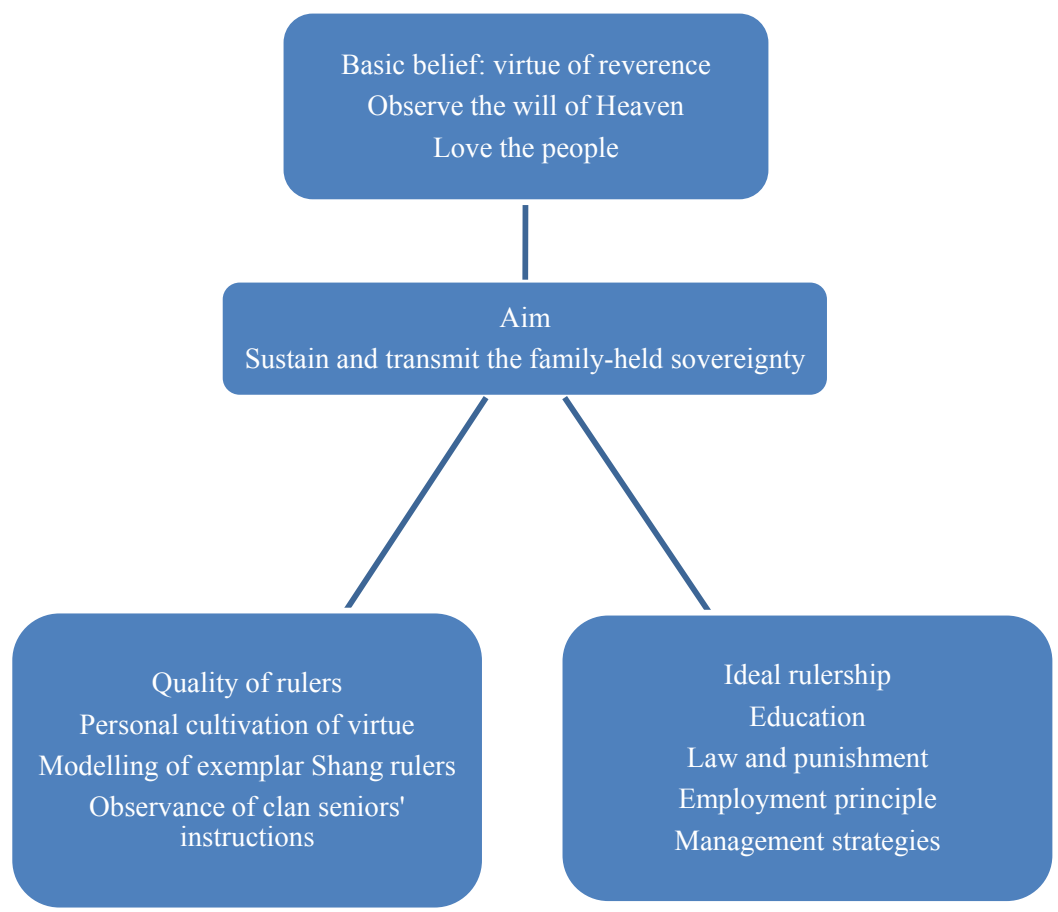

Figure 1. Framework of family sustainability in Ji Dan's family instruction

The aim of Ji Dan's instructions is to sustain and transmit the family held sovereignty. To actualize the aim, two basic beliefs "observe the will of Heaven" and "love the people" based on "virtue of reverence" are proposed to support the aim with a clear expectation of the quality of rulers and rulership as discussed in the previous sections. This functional framework is specifically applicable to the royal family of Zhou, the Jis.

Ji Dan is a holy figure of the royal Jis family of Zhou and his instructions represented in the five chapters are likely an idealization of rulership commonly held by Ji Dan's descendants in the declining period of the royal family (Kern, 2009). Why are Ji Dan's instructions represented in such a supreme status? It may be because the descendants of the royal family want to restore the feudal and patriarch systems adopted by Ji Dan to secure the declining sovereignty of the royal family of Zhou. At that time, the royal family was the owner of all resources in the nation and by implementing the feudal and patriarch systems, ownership of resources and roles could be defined clearly without disputes. Under these systems, all feudal lords were under the supreme ruling of the kings of Zhou. However, in the late Western Zhou and Eastern Zhou (770-221 BC) periods, this supreme status of the ruler family was challenged by strong feudal lords and mergers of states were common because of the increasing population of states (Jian, 1999). It is possible that under this political context, members of the royal family want to reiterate the legitimacy of the Jis to their descendants and other feudal lords through the speeches of Ji Dan. As a clan senior of the royal family, Ji Dan always emphasizes that King Wen is chosen by Heaven to take up the sovereignty and what he has done is just follow the ways of his ancestors King Wen and King Wu in the Book of Documents. In the chapter "Document on offering sacrifices to Heaven" (Fengchan shu) of the Records of Grand Historian (Shiji), it 
states that Ji Dan worships Heaven as well as King Wen (Han, 2004) and the inscription on the Tianwang gui, a ceremonial food vessel of King Wu for worshipping King Wen, also records that King Wen is monitoring his descendants in Heaven (D.C. Lau Research Centre for Chinese Ancient Texts, 2014b). All these prove that the people of Zhou hold a tradition of worshipping ancestors. This tradition established in the period of Shang was further developed by the early leaders of Western Zhou to strengthen the supreme status of clan seniors based on blood relation. The deification of ancestors is in fact the deification of the eldest son of the great clan or the royal family (dazong) (Liu, 1996). All other branches of the same clan are small clans (xiaozong) which are subordinates of the great clan. According to the patriarch system, only the eldest son of the great clan can be the successor of ancestors who can perform worship to Heaven and ancestors. This is a clear political and social class system which can settle the problem of "ownership" of resources and authority as well as advocate the supreme status of clan seniors. Under this political and ethical context, the supreme status of family instruction of clan seniors is emphasized which bears special meaning in times of dynastic decline and from a pronounced sense of loss and deficiency. The "updated" or "created" speeches of Ji Dan and other early Zhou leaders in the form of family instruction is a way to restore the authority of the royal family. Hence from this perspective, Kern's view on the time of these speeches of early Zhou leaders recorded in the Book of Documents can be confirmed.

The feudal system in the Western Zhou was based on blood relation in which the kings of Zhou belonged to the great clan (dazong) and were leaders of all small clans. Hence the kings and officials of the Western Zhou were all under the same clan or the same big family and that was a fusion of political and ethical relation. This kind of fusion also created class differentiation and role expectation. Within the same clan, members of small clans were all subordinates of the king (great clan) while within the small clans, members were also subordinates of their clan leaders according to their ages and roles. The smallest unit is what we mean core family nowadays which is formed by a couple and their children. The ethical behaviour of filial piety (xiao) is an ethical mechanism based on blood relation to maintain the harmony of the whole clan and the transmission of sovereignty. Filial piety is a core term in the ethics of Zhou which in general means respecting your ancestors, clan seniors and parents, and supporting their living (Liu, 1996; Zhou, 2006). In the chapter “Announcement about Drunkenness”, it records Ji Dan's saying:

Ye people of the land of Mei, if you can employ your limbs, largely cultivating your millets, and hastening about in the service of your fathers and elders; and if, with your carts and oxen, you traffic to a distance, that you may thereby filially minister to your parents:- then, when your parents are happy, you may set forth your spirits clear and strong, and use them (Jiugao, p. 1388; Legge, 1960b, p. 404).

Prince Kang is reminded by Ji Dan to educate the people of Yin whom they conquered. No matter whether farming or doing business far away they must take care of and respect their parents and elders. In this regard, observing clan seniors' and parents' instructions is a kind of filial piety practice. This can explain why the distant descendants of King Wen, King Wu and Ji Dan put up their ancestors' instructions to restore the authority of the royal family. In another chapter "Charge to the Marquis Wen" (Wenhou zhi ming), it records the king's words:

Uncle Yi-he, you render still more glorious your illustrious ancestor. You were the first to imitate the example of Wen and $\mathrm{Wu}$, collecting (the scattered powers), and continuing the all-but-broken line of your sovereign, your filial piety goes back to your accomplished ancestor, and is equal to his. You have done much to repair my losses, and defend me in my difficulties, and of you, being such, I am full of admiration (Lui, 1997, p. 254; Legge, 1960b, p. 618).

The meaning of "your filial piety goes back to your accomplished ancestor" (zhuixiao) is to follow up the works of their ancestors that is to maintain their sovereignty. Another key ethical concept with a close relation with filial piety in this period is paternal concern (ci) which refers to cultivation and care for children by the father. In the chapter "Announcement to the Prince of Kang", Ji Dan reminds Prince Kang:

O Feng, such chief criminals are greatly abhorred, and how much more detestable are the unfilial and unbrotherly! - as the son who does not reverently discharge his duty to his father, but greatly wounds his father's heart, and the father who can no longer love his son, but hates him; and the younger brother who does not think of the manifest will of Heaven, and refuses to respect his elder brother, and the elder brother who does not think of the toil of their parents in bringing them up, and is very unfriendly to his junior (Kanggao, p. 1336; Legge, 1960b, pp. 392-393).

The role expectations of father, son, elder brother and younger brother are stated in the paragraph. The senior members of the family and clan should love and care for their juniors while the junior members should also love and respect their seniors. Hence, senior members of the same clan and family are expected to care about their juniors' personal development and contribution to the clan and family. Family instruction is a medium for them 
to show their love and care. To demonstrate their respect to the seniors, juniors should normally follow their seniors' instruction. In this paragraph, those elder brothers who do not care about their juniors are taken as "unfriendly" (buyou). Although in this paragraph, only male members are referred to, the concept of filial piety also extends to the service provided by wife to husband before and after death in the period of Western Zhou (Wang, 1992).

The concepts of filial piety and paternal concern are two key ethical elements in this framework of family sustainability. This framework is not only valid for the sustainability of the royal family of Zhou as it can also be extended to family instruction of senior officials and common people by replacing its two basic beliefs with Confucian belief of benevolence (ren). The personal quality such as cultivation of virtue, modelling exemplar rulers and observance of clan seniors' instructions can be taken as Confucian ethical quality while the use of education, law and punishment, employment principles and management strategies are general administrative skills of officials. Wang (2006) pointed out that Confucianism was the major philosophy of Chinese family instruction which emphasized the responsibility of family members to try their best to sustain their family and clans. Zhu (2008) argued that the issue of personal cultivation in ancient China was in fact a fusion of family management and state ruling. This framework seems to be in line with their views and helps to explain why the Book of Documents was adopted as one of the five classics that students have to study.

\section{Conclusion}

In the above discussion, the five chapters of royal family instruction in the Book of Documents attributed to Ji Dan are studied in terms of educational aim and its philosophical beliefs, personal quality and ideal rulership with reference to the political and social context of the Western Zhou period. A framework of family sustainability which is supported by the ethical concepts of filial piety and paternal concern is constructed according to the findings. This framework can be extended from the royal family instruction to family instruction of officials and common people as sustainability of family is the major responsibility of Chinese and cultivation of virtue and development of administrative skills are still two key areas of education for Chinese. The relationships among royal family instruction, officials' family instruction and commoners' family instruction can further be explored to sort out the why and how the royal family instruction was transmitted to different social classes. The answer may help us understand more cultural variation of social class in the Pre-Qin period. In addition, further study of how ethical concepts such as filial piety and paternal concern in the Western Zhou family instruction are adopted by the Pre-Qin Confucianism may provide a new understanding of Confucianism.

\section{Reference}

Beijing Ri-bao. (2013). Tsinghua jian: Zaizheng chuanshi Shangshu quexi weiben (Qinghua bamboo slip: reconfirmation of forgery of the transmitted Book of Documents). Beijing: Beijing ribao.

D.C. Lau Research Centre for Chinese Ancient Texts. (2014a). Maogong ding (no. 2841), CHANT. Retrieved from http://80-www.chant.org.edlis.ied.edu.hk/jinwen/Default.aspx?p=660850

D.C. Lau Research Centre for Chinese Ancient Texts. (2014b). Tianwang gui (no. 4261), CHANT. Retrieved from $\mathrm{http}: / / 80$-www.chant.org.edlis.ied.edu.hk/ jinwen/Default.aspx?p=660850

Fu, Y. Q., \& Shi, W. D. (2008). Shangshu Pangengshang yu jiaxun de qiyuan (The first section of Panggeng of the Book of Shang and its relation to the origin of family instruction). Anhui Wenxue, 1, 80-81.

Gu, J. G., \& Liu, Q. Y. (2005). Shangshu jiaoshiyi lun (Discussion, Annotation and Translation on the Book of Documents). Beijing: Zhonghua shuju.

Jian, B. Z. (1999). Xianqin shi (History of the Pre-Qin period). Beijing: Beijing daxue chubanshe.

Han, Z. Q. (2004). Shiji jianzheng (Commentary and clarification on the Records of Grand Historian). Nanchang, Jiangxi: Jiangxi renmin chubanshe.

Huang, H. X. (1992). Yizhoushu yuanliu kao (Study on origin of the Lost Book of Zhou). Xian, Shaanxi: Xibei daxue chubanshe.

Kang, S. C. (2009). Hanwei liuchao jiaxun yanjiu (Study on family instruction of the Hanwei and Liuchao Period). Taipei, Taiwan: Huamulan wenhua chubanshe.

Kang, X. W. (1992). Xianqin xiaodao yanjiu (Study on filial piety in the Pre-Qin Period). Taipei, Taiwan: Wenchin Publishing House. 
Kern, M. (2009). Bronze inscriptions, the Shijing and the Shangshu: the evoluation of the ancestral sacrifice during the Western Zhou. In J. Lagerwey and M. Kalinowski (Eds.), Early Chinese Religion, Part One: Shang Through Han (1250 BC to 220 AD) (pp. 143-200). Leiden, Dutch: Brill.

Legge, J. (1960a). The Chinese Classics (Volume Two) (The Works of Mencius). Hong Kong: Hong Kong University Press.

Legge, J. (1960b). The Chinese Classics (Volume Three) (The Shoo King). Hong Kong: Hong Kong University Press.

Liao, M. C. (2001). A preliminary study on the newly-unearthed bamboo inscriptions of the Chu kingdom: an investigation of the materials from and about the Shangshu in the Guodian Chu slips (in Chinese). Taipei, Taiwan: Taiwan Guji Publishing Company.

Liu C. M. (2002). Lidai jiaxun yu gudai jiating jiaoyu de jiazhi quxiang (Family discipline and value conception of ancient family education). Henan shifan daxue xuebao (zhexue shehui kexue ban), 29(4), 112-114.

Liu, Z. H. (Ed.). (1996). Zhongguo zhengzhi sixiangshi (xianqin juan) (History of Chinese political thought) (Pre-Qin section). Hanzhou, Zhejiang: Zhejiang renmin chubanxhe.

Lu, J. (Ed.) (1997). Shisab jing zhushu (Commentary and sub-commentary on the Thirteen Classics). Shanghai: Shanghai guji chubanshe.

Shaughnessy, E. L. (2006). Rewriting early Chinese texts. New York, NY: SUNY Press.

Sun, P. Q., \& Li, G. J. (1995). Zhongguo jiaoyu sixiang shi (History of Chinese educational thought) (Volume 1). Shanghai: Huadong sifan daxue chubanshe.

Tong, H. K. (2013). The Chinese jiaxun (Family instruction) in Pre-Qin (Before 221BC) Literature. International Journal of Humanities and Social Science, 3(9), 204-212.

Yang, C. M. (2008). Yizhoushu suojian mieshang zhiqian de Zhougong (Zhougong before annihilating the Shang dynasty in "Yizgoushu"), Journal of Henan University of Science and Technology (Social Science), 26(1), 16-24.

Wang, G. Y. (Ed.). (2013). Zhongguo wenhua tongshi (Comprehensive history of Chinese culture). Beijing: Beijing shifan daxue chubanshe.

Wang, Z. J. (2006). Chuantong jiaxun sixiang tonglun (General discussion on the thoughts of traditional family instruction). Changchun, Jilin: Jilin renmin chubanshe.

Wang, L. H. (2007). The Origin and Early Development of Chinese Family (from the Period of Pre-Qin to the Southern and Northern Dynasties). In Zhang Guogang. (Ed.), A General History of Chinese Family (volume1). Guangzhou, Guangdong: Guangdong Peoples Publishing House.

Wang, S. X. (1992). Guwenzi yu wenming (Ancient characters and culture). Xian, Shaanxi: Shaanxi jiayu chubanshe.

Zeng, F. Z. (2006). Lun Zhongguo chuantong jiaxun de xiyuan, tezheng ji qi xiandai yiyi (On Chinese traditional parental instruction's origin, characteristic and its modern significance). Journal of Huaihua University, 25(4), $1-4$.

Zhou, Z. Q. (2006). Zhongguo gudai sixiangshi (History of ancient Chinese thought). Nanling, Guangxi: Guangxi renmin chubanshe.

Zhu, M. X. (2008). Zhongguo jiaxunshi lungao (Discussion on history of Chinese family instruction). Chengdu, Sichuan: Bashu shushe.

\section{Copyrights}

Copyright for this article is retained by the author(s), with first publication rights granted to the journal.

This is an open-access article distributed under the terms and conditions of the Creative Commons Attribution license (http://creativecommons.org/licenses/by/3.0/). 